\title{
Fostering Critical Intercultural Awareness Among efl Students Through Critical Discourse Analysis
}

\author{
FOMENTO DE LA CONSCIENCIA CRÍTICA INTERCULTURAL EN ESTUDIANTES DE INGLÉS \\ COMO LENGUA EXTRANJERA MEDIANTE EL ANÁLISIS CRÍTICO DEL DISCURSO \\ Promouvoir la conscience Critidue interculturelle Chez des étudiants en \\ ANGLAIS LANGUE ÉTRANGÈRE EN UTILISANT L'ANALYSE CRITIQUE DU DISCOURS
}

\author{
Abduljalil Nasr Hazaea \\ Ph. D. and M. A. in English Language \\ Studies, National University of \\ Malaysia. \\ Assistant Professor of Applied \\ Linguistics, Najran University, Saudi \\ Arabia. \\ Saudi Arabia, Najran, King Abdulaziz \\ Road P. O. Box 1988 \\ agaleel@gmail.com \\ https://orcid. \\ org/0000-0002-1950-2153
}

\begin{abstract}
This paper reports some findings on the development of critical intercultural awareness among English-as-a-foreign-language students in the context of a critical reading enrichment course for students in the preparatory year at a Saudi university. The critical reading class aimed to increase levels of critical intercultural awareness among the participants when they decoded and encoded an intercultural text. A qualitative action research design was used. The teacher-researcher equipped the participants with tools from critical discourse analysis for analyzing intercultural texts. After that, they were asked to work on an assignment by reading a text about a dinner invitation and then writing creatively on that topic. The study data were collected from these reflective writings in the participants' portfolios. The teacher-researcher also used tools of critical discourse analysis to analyze the collected data. It was found that the participants demonstrated a balanced intercultural awareness associated with the discourse of food diversity. They also effectively appreciated cultures of the self and others and demonstrated appropriate intercultural knowledge of the self and others. Furthermore, they acquired the intercultural skills of relating to intercultural texts, as well as analyzing and interpreting them. The study suggests the effectiveness of critical discourse analysis as a teaching and learning strategy to increase critical intercultural awareness among English-as-a-foreign-language students.
\end{abstract}

Keywords: critical intercultural awareness; critical discourse analysis; English as a foreign language; critical reading; action research; EFL.

\section{RESUMEN}

Este artículo presenta algunos hallazgos sobre el desarrollo de la conciencia crítica intercultural en estudiantes de inglés como lengua extranjera en el contexto de un curso de afianzamiento en lectura crítica en el programa preparatorio de una universidad saudí. En su carácter de actividad extracurricular, la clase de lectura crítica busca incrementar la conciencia crítica intercultural entre los participantes, al codificar y decodificar un texto intercultural. Se empleó un diseño cualitativo de investigación acción. El docente investigador suministró herramientas de análisis

Received: 2018-11-26 / Accepted: 2019-04-26 / Published: 2020-01-28

DoI: $10.17533 /$ udea.ikala.v25n01a06 
crítico del discurso a los participantes para examinar textos interculturales. Después de eso, les pidió que trabajaran en un ejercicio que consistió en la lectura de un artículo sobre una invitación a cenar para luego hacer un ejercicio de escritura creativa sobre ese tema. Los datos para el estudio se recolectaron de estos escritos de reflexión contenidos en los portafolios de los participantes. El docente investigador también empleó herramientas de análisis crítico del discurso para analizar los datos recolectados. Se halló que los participantes presentaron una conciencia intercultural balanceada asociada con el discurso de la diversidad alimenticia. Apreciaron efectivamente las culturas 'propia' y de los 'otros'. También representaron un conocimiento apropiado de 'sí mismos' y 'de los otros'. Los participantes adquirieron habilidades interculturales de análisis, interpretación y asociación de textos interculturales. El estudio muestra la eficacia del análisis crítico del discurso como estrategia de enseñanza y aprendizaje para enriquecer la conciencia intercultural crítica entre los estudiantes de inglés como lengua extranjera.

Palabras claves: conciencia crítica intercultural; análisis crítico del discurso; inglés como lengua extranjera; lectura crítica; investigación acción; ILE.

\section{RÉSUMÉ}

Cet article présente des résultats du développement de la conscience critique interculturelle chez des étudiants ayant l'anglais comme langue étrangère qui ont suivi des cours de lecture critique dans le cadre de l'année préparatoire á l'entrée dans une université saoudienne. Ce cours vise à accroître le niveau de conscience critique interculturelle des participants lorsqu'ils lisent et écrivent des textes multiculturels. L'étude s'est appuyée sur une méthode procédurale qualitative. L'enseignant-chercheur a fourni aux participants des outils d'analyse critique du discours pour analyser les textes multiculturels. Il leur a ensuite été demandé de lire un article sur une invitation à dîner, puis d'élaborer un écrit sur le même sujet. Ces écrits font partie du corpus. L'enseignant-chercheur a également utilisé des outils d'analyse critique du discours pour analyser les textes du corpus. Les résultats ont montré que les participants ont fait preuve $\mathrm{d}$ 'une conscience interculturelle équilibrée associée à un discours sur la diversité alimentaire. Ils ont également montré qu'ils appréciaient et connaissaient bien leur culture et la culture de l'autre. De plus, les participants ont acquis des compétences en communication interculturelle qui leur permettent d'associer, d'analyser et d'interpréter des textes multiculturels. Finalement, cette étude a révélé l'efficacité de l'analyse critique du discours en tant que stratégie d'enseignement et d'apprentissage pour accroître la conscience critique interculturelle chez les étudiants ayant l'anglais comme langue étrangère.

Mots clés : conscience critique interculturelle ; analyse critique du discours ; anglais langue étrangère ; lecture critique ; recherche action; ALE. 


\section{Introduction}

Saudi Arabia is modernizing its (inter)cultural education (Elyas, 2014) to account for the needs of $21^{\text {st }}$ century intercultural communication. However, critical language awareness is not widely practiced in Saudi English as a foreign language (EFL) classes because of teaching materials, teaching practices, and students' lack of intercultural skills. English language instruction was first introduced to Saudi schools in the late 1950s (Al-Ghamdi \& Al-Saddat, 2002) with what Mahboob and Elyas (2014) called locally-oriented content, which neglected other cultures (Elyas, 2008). Later on, Alfahadi (2012) found that Saudi EFL teachers were not satisfied with the cultural content in the textbooks they were using because they believed it inappropriately contradicted the local cultural values, and Ahmad (2015) found that the exclusion of Saudi culture from EFL textbooks may have a negative impact on students. In English undergraduate education, Elyas (2011) also reported that "little or no attention is paid to the effect of culture and discourses/ discourses in university English courses" (p. 100). Elyas (2014) further highlighted the issue of "the complex learning identities of [EFL] Arab youth and the need for a more sophisticated curriculum development within this context" (p. 28). Alkatheery, Al Saleh, and Isama (2010) found balanced representation of the cultures of centre and periphery countries in the Interactions/Mosaic textbook series for the Middle East, which are widely used in Saudi Arabia for undergraduate students in English language programs. But, as seen throughout this experience at a Saudi university with students in their preparatory year, the matter is not only with teaching materials but also with teaching and learning practices that need to keep a balance between linguistic competence and intercultural competence.

Previous research has also called for critical intercultural awareness (CIA) among Saudi EFL students. For example, Hazaea and Alzubi (2017) recommended enhancing CIA among Saudi EFL reading classes. Earlier, Benahnia (2014) had argued that intercultural competence and the concept of identity could be used as vehicles toward a better understanding and acceptance of others (as opposed to the self). Furthermore, Fageeh (2011) claimed that EFL teachers should never neglect the significance of both local and global cultures in EFL teaching and should make an effort to enhance students' intercultural awareness. In the same vein, Alfahadi (2012) revealed that Saudi EFL teachers show their openness to other cultures based on their glocal position as local Saudis teaching a global language. But Aldosari (2013) revealed that students' heritage was a significant factor that affected their performance in cross-cultural competence and their perceptions of the relationship between language and culture. Anyhow, Saudi EFL classes remain fixed in a decontextualized conception of literacy, and intercultural education is not explicitly introduced.

To address this issue, an interventional action research project investigated CIA in the portfolios of EFL students in their preparatory year at a Saudi university. The pretreatment findings were reported in Hazaea (2018), where the participants showed a lack of intercultural competence in their baseline portfolios. The present paper reports the post interventional findings on CIA among the same students after introducing critical discourse analysis (CDA) tools in a critical reading enrichment class. This paper aims to reveal the students' cultural awareness as it pertains to the self and others when associated with food diversity discourse in an intercultural assignment. To help students develop critical reading skills, CDA tools (Appendix) were provided to the students. After that, students were given an intercultural assignment to critically read a story about a dinner invitation and creatively write on that topic.

CDA provides researchers, teachers, and students with linguistic tools for intercultural text analysis. It investigates ideologies (Wodak, 2002) that are represented (Fairclough, 2003) by language use and provides tools with which researchers can analyze texts. It also gives teachers techniques to pass on to their students, so they are equipped to analyze intercultural texts, enhance their CIA, and become more productive readers (Svarstad, 2015). Although extensive research has 
been reported on the use of $\mathrm{CDA}$ by researchers, only a few studies have involved introducing these tools to students to enhance CIA. For example, Abbasian and Malaee (2015) used CDA techniques to generally improve Iranian EFL learners' ability to read between the lines. In this case, CDA tools were introduced for the sake of enhancing CIA among Saudi EFL students.

\section{Theoretical Framework}

This section subsumes critical language awareness and intercultural awareness in the form of CIA. It deals with culture as discourses, and levels of CDA as tools for intercultural awareness. This section also reviews the literature on CIA and CDA. In so doing, it finds out the existing gap on CIA in EFL reading classes.

\section{CIA and CDA}

Language and culture are intertwined, like two sides of the same coin. More recently, there has been an increase in discussions on adopting sociocultural approaches that treat language learning as a social activity. This article subsumes critical language awareness (Wallace, 1999) and intercultural awareness (Baker, 2012; Chen \& Starosta, 1998; Escudero, 2013; Korzilius, van Hooft, \& Planken, 2007; Zhang \& Steele, 2012) into the concept of CIA. Accordingly, this paper operationalizes CIA as the ability of EFL students to effectively and appropriately decode and encode cultures of self and others as intercultural competitive discourses associated with an intercultural topic in intercultural texts. This understanding involves both objectivist and ideologist positions towards discourse (Fairclough, 2006). While the objectivist position deals with an intercultural topic, the ideologist position investigates power relations between self culture and other culture as intercultural competitive discourses. These discourses involve intercultural attitude, intercultural knowledge, and intercultural skills (Byram, 1997; Oranje \& Smith, 2018).

Intercultural competitive discourses are represented in intercultural texts. Escudero (2013) operationalized culture as discourse, while Fairclough (2003) pointed out that "we can look at texts from a representational point of view" (p. 136) in the form of discourses, which reflect the representational function of language. Wallace (1999) operationalized Fairclough's view in a critical reading classroom where critical language awareness involved notions of emancipation, difference, and opposition.

To enhance CIA in a reading classroom, introducing CDA tools can be of practical relevance. Teaching $\mathrm{CDA}$ in the classroom goes beyond raising students' awareness of purely linguistic issues (Wallace, 1992); it necessitates highlighting the effect of social power(s) on text composition (Fairclough, 1995). Gaining awareness of CDA also helps students build intercultural rapport by reading intercultural texts. Fairclough established three overlapping levels of CDA: textual analysis, discourse analysis and critical discourse analysis.

These CDA tools (Fairclough, 1995; Janks, 1997) can be simplified and explained to EFL students for the purpose of analyzing intercultural texts. While the sociocultural and discourse levels of analysis can be introduced in the form of questions, the textual level of analysis can instead be explained in terms of systemic functional grammar. This approach would give strategic guidance to improve discourse production through the identification of discourse patterns, clause relations, and genres (DudleyEvans, 2002, p. 220). The acquisition of CDA tools promotes the logical organization of ideas and reinforces CIA.

\section{CIA in EFL Contexts}

In Saudi Arabia, English instruction has been extended into primary schools in response to demands for exposing Saudi youth to the idea of harmony and tolerance with other cultures (Elyas, 2008). Previous research has also called for investigating intercultural competence among Saudi EFL students (Ahmad, 2015; Aldosari, 2013; Alfahadi, 2012; Alkatheery et al. 2010; Benahnia, 2014; Elyas, 2014; Fageeh, 2011; Hazaea \& Alzubi, 2017). 
In the Chinese EFL context, Ran (2008) found that inculcating learners' own culture can help them to develop a critical awareness of selfness and otherness. In the same vein, Liu and Fang (2017) investigated intercultural awareness of Chinese culture among Chinese EFL undergraduate students. The study recommended the integration of world cultures into English language teaching. Similarly, Fang (2018) called for intercultural citizenship as an alternative model in English language teaching. These studies highlight the need for CIA among EFL students.

In some other countries, Escudero (2013) suggested that the field of intercultural education needs to take a linguistic turn in order to advance its goals. Byram (1997) treated intercultural competence as the ability to understand and deal with cultural differences without ethnocentricity. Ho (2009) examined the effect of intercultural language learning on Vietnamese EFL learners where the cultural component helped competent learners linguistically and culturally. Meanwhile, Weninger and Kiss (2013) problematized the quantitative approaches used at the time to analyze culture in foreign language textbooks as objectifying culture. Weninger and Kiss concluded that focusing on linguistic competence is not enough for fostering intercultural citizenship and critical understanding of the self and others in foreign language learning.

EFL teaching and learning have devoted significant attention to intercultural identities and the notion that learners simultaneously acquire cultural and linguistic knowledge (Nugent \& Catalano, 2015). In intercultural communication, Nugent and Catalano added that EFL learners act as exchangers of their own culture and other cultures. The same authors held that EFL students should become aware of the latent layers of meaning within intercultural texts. According to Hazaea, Noraini and Nor Fariza (2014), moreover, intercultural communication will help EFL students to represent intercultural balance between their own ideologies and those of others. Moncada Linares (2016) found that, in the absence of critical thinking, EFL students are subjected to cultural misunderstanding in which they either impose their own culture on others or are overwhelmingly inculcated with other cultures. Therefore, it is necessary for EFL students to play a vital role as global citizens to exchange and transmit cultures of peace, shared identity, and civilization (Porto, Houghton, \& Byram, 2018).

EFL students used to pay more attention to linguistic competence while reading (Zinkgraf, 2003) and writing. They used to neglect the ideological load of certain expressions or words (Oughton, 2007), something that Wallace (1992) problematized as language unawareness. Since then, English language reading and writing have been extended beyond linguistic competence into intercultural competence. To develop CIA, moreover, EFL students must go beyond linguistic competence by reading and writing in a culturally appropriate way.

\section{Method}

Using an empirical action qualitative research design, an interventional project aimed to investigate CIA in the pre- and post- treatment reflective writings in the portfolios of EFL students in their preparatory year at a Saudi university. The present paper reports the post-CIA treatment findings after introducing tools of CDA to the selected students for use in analyzing intercultural texts.

\section{Context and Settings}

In many Saudi universities, preparatory year is compulsory for new students who will join competitive undergraduate programs such as medicine and engineering. In the Saudi university in this study, around eight hundred male students are enrolled every year. These students share similar characteristics such as sex, age, and linguistic and cultural background. The Saudi education system requires that males and females be separated, so all students in this study were male. The students' ages ranged between 18 and 21. Arabic and Saudi 
culture were their first language and culture, English was considered a foreign language for them, and the cultures of the English-speaking parts of the world were also considered foreign for them. The students were randomly categorized into sections by semester rather than level, so in a single classroom, the students had a wide range of English proficiency levels, from very high to very low. The students were required to complete intensive English language courses, including reading and writing courses, in two semesters. Each semester, they sat for two midterm exams and one final exam. After the first midterm, two extracurricular activities were conducted: remedial classes for low proficiency students and enrichment classes for high proficiency students.

After the first midterm, high proficiency students were given a tailor-made critical reading enrichment class. The class consisted of intercultural reading materials and CDA tools, aiming to increase the students' level of intercultural awareness when decoding and encoding intercultural texts. The students were to use the CDA tools to analyze intercultural texts and subsequently increase their awareness of self and other cultures. An announcement was publicly made for students who scored highly on the first reading midterm to join an ungraded critical reading class if interested.

The intercultural textbook materials were drawn from Kirn and Hartmann's (2012) Interactions reading textbook. The intercultural newspaper materials were selected based on the following criteria: intercultural content, suitability to the participants' English level, produced by Saudi writers, and distributed in Saudi newspapers. Additionally, the participants collected intercultural news stories from Arab News, which is the first daily English language broadsheet available in online and print formats in Saudi Arabia. This newspaper deals with Saudi, Middle East and world business, sports, lifestyle, culture and opinion issues.

\section{Roles of Teacher-Researcher and}

\section{Participants}

Reporting action research requires the researcher to specify his role. The teacher-researcher in charge of this study has keen interests in CDA for intercultural communication and at the same time he shares many cultural codes with the participants. Therefore, as a teacher, he introduced CDA tools to the participants in order to enable them to analyze intercultural texts. As a researcher, he used CDA tools to analyze the collected data, that is, the intercultural assignments that the participants completed during the enrichment classes.

The selected intercultural texts were used as the training materials in a ten-session treatment. Each session lasted one hour. In the first session, an hour was devoted to guide participants interested in the class. At this stage, he discussed the participants' consent to participate in the research project, the nature of the ungraded extracurricular enrichment class, and the development of the students' portfolios. These sessions were conducted two times a week during the first semester in 2016. Fifteen students regularly participated in the critical reading class. During training sessions, the participants were randomly divided into two competitive role-playing groups: a self culture group (A) and other culture group (B).

After each training session, the participants were given a critical reading assignment. Toward the end of the intervention, the participants worked on an intercultural assignment. The teacher used the topic of a dinner invitation as Saudi culture revolves around generosity and food. This topic was chosen because of the interest it might arouse in the participants and the manifold opportunities it might present for intercultural encounters. The teacher-researcher asked the participants to critically read the assigned text and then write a similar story about a Middle Eastern businessman who is invited by an American businessman to a restaurant in New York.

\section{CDA Tools}

The CDA tools provided to the Saudi EFL students were intended to assist them in reading and writing intercultural texts. The tools were presented in such a manner that they helped the participants to become 
aware of the role of the English language in fostering CIA in a world that is becoming increasingly glocal. When analyzing an intercultural text, the student should read it three times, so that three overlapping levels of analysis were covered. The researcher then prepared a list of CDA tools for analyzing intercultural texts (Appendix). He simplified the linguistic tools, which were taken from CDA and systemic functional grammar (Janks, 1997) and introduced them to the participants for analyzing intercultural texts. These tools were presented as three overlapping levels of analysis: textual analysis, discourse analysis, and CDA.

For textual analysis, functional grammar terms were linked with traditional descriptive grammar. For example, terms like participants or social actors were explained as subjects or objects. Also the terms 'action verbs' and 'linking verbs' were used instead of CDA terms for processes: thinking, saying, seeing, and doing. Adverbs were used to explain the circumstances of time and place. 'Vocabulary' was used to explain lexical choices manifested in word meaning and wording. The main goal was to use the tools to reveal the writers' ideological choices and representations.

For discourse analysis, the participants were trained to question how were the intercultural texts produced?, and who are the target audience? Who are the writers of the texts? Why do the writers choose certain words/phrases? Can this text be given to international students? At this level of analysis, the participants were able to analyze the text in relation to the original (source) text. For CDA, the participants questioned the power relation between self and others in the texts. These questions included sociocultural questions such as: Did the writers consider local and other cultures when they wrote the texts? Did readers agree with the writer regarding the images he/she presented of local and other cultures in the text? After going through the three levels of analysis, it was expected that the participants would be able to reveal self and other discourses evident in an intercultural text.

\section{Data Collection}

Guided by the research objectives, the data were collected through written discourse. After training the participants to use the CDA tools, they were asked to read a story about a dinner invitation and then write a similar story. The posttreatment assignment was included in the students' portfolios. The assignment aimed to shift the students from being passive readers to active producers of intercultural texts. While the participants would decode the assigned text, they could also represent their own ideological choices and CIA in written form. In their assignment, the participants were supposed to reflect on their CIA by providing linguistic evidence in written form. They would analyze (decode) the texts and write (encode) a similar text outside of class because there would be no time limitation, allowing them to work with more care and with little to no pressure.

In reflective journal writing, the students analyzed the effectiveness of their efforts to improve (Kathpalia \& Heah, 2008) intercultural awareness. Reflective writing proved to be an effective tool for developing students' portfolios and academic writing (Romova $\&$ Andrew, 2011). After the participants submitted their assigned text, their texts were coded as (IA-n) where (I) stands for intercultural, (A) for assignment and $(\mathrm{n})$ for the sequence number of the participant (1-15). In this way, data were collected and compiled for analysis after getting the participants' approval.

\section{Data Analysis Procedures}

The collected data as discourses were analyzed using CDA tools. To reveal a discourse, this type of analysis applies three levels of analysis to intercultural texts. A theme is described at the textual level of analysis. It is also interpreted at the level of discourse practice and explained at the sociocultural level. But the emerging ideas at any level do not determine the shape of a discourse. It is in the combination of these three overlapping levels that a discourse appears in its final form (Janks, 1997). 
Huckin (1997) pointed out that not every CDA tool is equally useful when analyzing texts, and the researcher should choose only those which are most interesting from a critical perspective and those that reveal the writer's purposes. These tools appear in the form of questions at the explanation and interpretation levels, and as specific tools at the description level. For the descriptive textual analysis, CDA deals with tools originally grounded in Halliday's functional grammar (1985). These tools include transitivity and choices of modality. The clause is the unit of analysis, where the focus is on participants, processes, and circumstances. Participants are manifested in the form of nouns, subjects, and objects. Van Leeuwen (1996) referred to the participants as social actors. Five types of processes are distinguished: material, verbal, mental, relational, and behavioral (Fairclough, 2003; Halliday, 1985). Circumstances are manifested in the adverbials of time and place. For the interpretation discourse analysis, the analysis moves to the processes of production and consumption of the text, and the situational and intertextual contexts. The expla-

24 nation of $\mathrm{CDA}$ is presented in the form of questions pertaining to the self and others, including interests that relate discourse to relations of power: How is the text positioned or positioning? Whose interests are served by this positioning? What are the consequences of this positioning (Janks, 1997)? CDA seeks to understand how discourse is implicated in relations of power between the self and others in intercultural texts.

\section{Results}

In this study, CIA was operationalised in the form of intercultural competitive discourses associated with the discourse of food diversity. Cultural discourses of the self were identified in relation to those of others, as shown in Table 1. In accordance with Deardorff (2006), CIA was classified into intercultural attitude, intercultural knowledge, and written intercultural skill.

\section{Food Diversity Discourse}

The data analysis showed the discourse of food diversity as nodal discourse (Fairclough, 2006) around which intercultural competitive discourses clustered. The following reflective writing provides an example of this discourse:

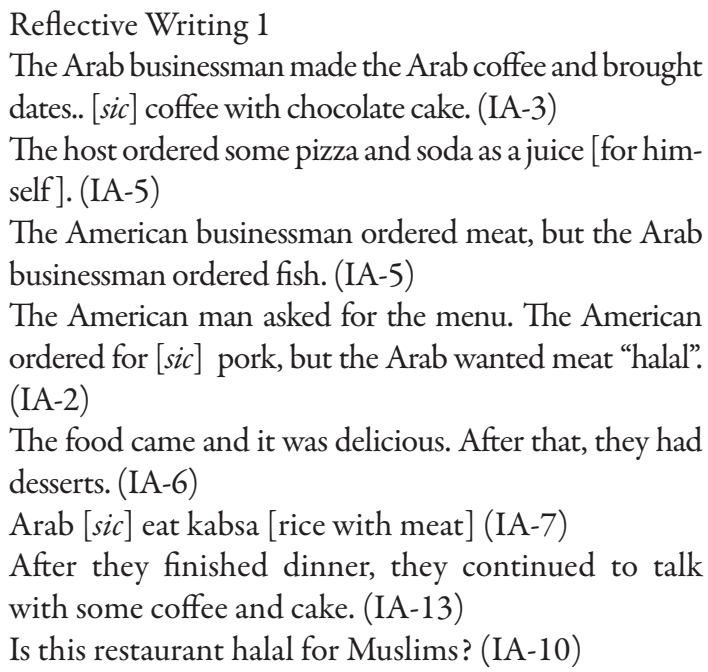

In these clauses, self social actors and other social actors negotiate about food choices. This is manifested in verbal processes such as ask and material processes such as ordered, eat and drink. These types of processes indicate a level of mutual interaction among the self social actors and other social actors

Table 1 Critical Intercultural Awareness Associated With the Food Diversity Discourse

\begin{tabular}{ll}
\hline Critical Intercultural Awareness & \multicolumn{1}{c}{ Intercultural competitive discourses } \\
\hline Intercultural attitude & Discourse of mutual appreciation \\
& Discourse of mutual understanding \\
& Discourse of mutual politeness \\
\hline Intercultural knowledge & Discourse of self as guest; discourse of others as host; Saudi national \\
& discourse; American national discourse; Arab regional discourse; \\
& discourse of time adaptation \\
\hline Intercultural skills & Skills to decode intercultural assignment, to interpret intercultural \\
& embedded messages, and to represent intercultural awareness in \\
& intercultural texts (Appendix) \\
\hline
\end{tabular}


about food. Food diversity is represented in wording such as coffee, Arab food, halal, pork, fish, international restaurant, kabsa, dates, pizza, soda, juice, and dessert.

Food choice is shaped by religious, cultural, and environmental factors (Alonso, 2015). The religion of Islam generally forbids the consumption of pork, so most Muslims do not eat it. However, the participants understood that they can eat halal food, and the host can eat pork with them at the same table. Saudi people prefer a small cup of coffee or tea as hot drinks before and after meals. They are commonly served with dates as an accompaniment. Interestingly, not a single word about drinking alcohol was reported to have been used at the table shared by the Arab and American businessmen. Like pork, alcohol is not permitted by Islamic rules. In this case, drinking alcohol is believed to cause absence of mind. That is why the participants did not expect alcohol to be served. Anyhow, these are some manifestations about food diversity.

\section{Intercultural Attitudes}

Three discourses represent intercultural attitude: mutual appreciation, understanding, and politeness. The data analysis revealed that there was discourse of mutual appreciation as manifested in the following clauses:

\author{
Reflective Writing 2 \\ When they met in the restaurant, they started gree- \\ ting. (IA-4) \\ Finally the Arabic man thanked his host and left. \\ (IA-11) \\ The host told him "I really want you to visit me again \\ and again." (IA-9) \\ At the end, he [the guest] will be thankful. (IA-12) \\ The Arabic man thanked the American friend for the \\ nice meal. (IA-13) \\ The Arab said [sic] "Thank you, I enjoyed it." (IA-6) \\ The guest thanked the host and he left. (IA-9) \\ He appreciated the dinner and, as a payback, invited \\ the host. (IA-1) \\ They will be thankful for the American businessman. \\ (IA-8)
}

In these clauses, the self social actor is the main actor. It is foregrounded in these clauses as the doer.
This doer is associated with verbal processes such as thank, appreciated, and enjoyed. Because he is in the context of the other, the self social actor is represented as the doer of the discourse of appreciation. The repetition of the word again and use of the phrase as a payback reflect the importance of mutual invitations in Saudi culture. In such invitations, each party shows appreciation to the other.

The data analysis also revealed the existence of discourse of mutual understanding as shown in the following reflective writing:

\section{Reflective Writing 3}

The American host understands that the two brothers used to eat by [sic were used to eating with] their hands instead of the spoons. (IA-8)

The American host was surprised from [sic by] Arab people because they keep [sic kept] kidding and enjoying [themselves] a lot. Then he became so happy. (IA-1)

There are some similarities and differences between Arab culture and American culture. IA-4)

The two men had a nice conversation, (IA-10)

In these clauses both self social actors and other social actors are represented as accepting each other. The self social actors use their hands, while the other social actors use spoons. Although the mental process surprised was used, it was done so in a positive context. Emotive expressions were manifested in this discourse such as happy and kidding. Self and other social actors were also associated with each other as doers, as expressed in the two men.

The data analysis also showed that there was discourse of mutual politeness as manifested in the following reflective writing:

Reflective Writing 4

The guest whispered politely to his host. (IA-11)

The American businessman noticed that the Arabic businessman was so polite with the American and when he needed something he always asks [sic asked] in a polite way. (IA-4)

After both of them had a nice meal, the guest asked politely to go for him to go sleeping [sic to sleep]. (IA-13)

So the Arab businessman apologized to the American, and the American invited him again another time. (IA-14) 
In these statements, the word polite is repeated and politely is used once. They are associated with both the self social actor and the other social actor. In this communicative business event, the participants demonstrated positive attitudes toward both their self cultures and the other cultures.

\section{Intercultural Knowledge}

Six discourses represented intercultural knowledge in this study. These discourses are discourse of self as guest, discourse of others as host, Saudi national discourse, American national discourse, Arab regional discourse and discourse of time adaptation (Table 1). The data analysis revealed that discourse of self-asguest compromises discourse of other-as-host. These compromising discourses were identified by examining the use of social actors in some clauses. The following reflective writing shows these types of discourse.

\section{Reflective Writing 5}

The host came on time. (IA-1)

The host ordered some pizza. IA-3)

Asked the host [sic] Sure" replied the guest. (IA-5)

The host ordered two dishes and juice. Then the guest came. (IA-14)

The guest thanked the host. (IA-9)

He [the guest] will start comfortable small talk with his host. (IA-7)

In these statements, the self social actor was the guest, while the other social actor was the host. This is evident in the above clauses and other examples disseminated in the analysis. The self social actor as the guest was associated with the verbal processes asked and replied and the material process came. The other social actor as the host was associated with the material processes came and ordered.

The data analysis also revealed the presence of Arab regional discourse and Saudi national discourse in relation to American national discourse as it is evident in the following reflective writing.

Reflective Writing 6

The Arabic man thanked the American friend for the nice meal. (IA-10)
There are some similarities and differences between Arab culture and American culture. (IA-4)

The Saudi got there on time. (IA-5)

These statements show that Arab regional discourse is represented instead of the Middle Eastern discourse represented in the assignment. In addition, one participant represented the self social actor with Saudi national discourse as can be seen in the last clause. The teacher observed that, at the beginning, the participants were eager to join the self group rather than the other group. The participants gradually became interested in the classes and CDA tools for revealing self and other discourses in intercultural texts.

The data analysis also revealed multiple instances of discourse of time adaptation of the other as is evident in the following excerpt:

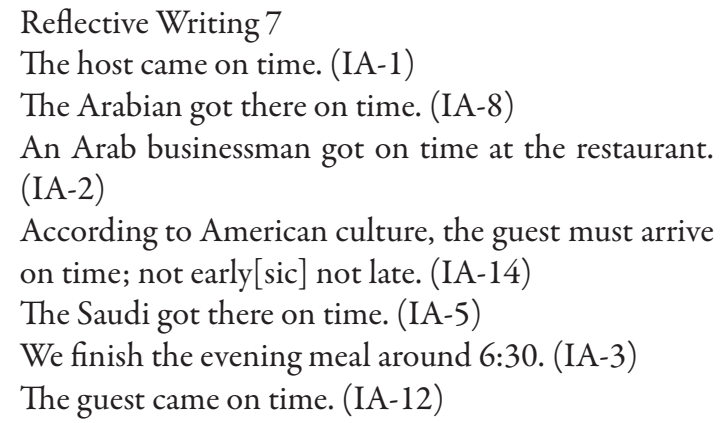

This discourse is manifested in adverbial phrases of time such as on time, not early not late which were associated with the self social actor. Being in the other context, the self social actor is adapting to the other's timing. This timing adaptation is associated with material processes such as got, came, and arrive. Cultural expressions are used this time to explain cultural differences such as the use of the word culture. Because of recontextualization, there was no indication that the other social actor was late.

\section{Intercultural Skills}

Intercultural skills were manifested in the form of the participants' ability to use the CDA tools to analyze (textual analysis), interpret (discourse analysis), and relate (CDA) in an intercultural clause (Appendix).

For textual analysis, the participants showed increased ability to analyze a sentence not only as a linguistic 
unit of descriptive grammar, but also a unit of analysis for intercultural texts. They also showed an increased ability to decode and encode intercultural messages disseminated in the intercultural texts used in the course. The terms subject, object, action verb, linking verb, modals, adjectives, adverbs gained new connotations for them. They learned that self identity can be foregrounded as subjects, other identity can be backgrounded as objects, and vice versa. They learned that linking verbs reflect believe and equality, while action verbs imply various layers of representation. The participants demonstrated that they developed awareness that the choice of models has different levels of certainty and attitude, and that adverbs of time and place indicate how much space is given to national identity in intercultural communication.

For discourse analysis and CDA, at the end of the classes, the participants demonstrated increased awareness that textual analysis alone is not enough to grasp the intercultural meanings embedded in intercultural texts; they need to investigate the producers of the text, the target readers of the text, and the genre of the text. Finally, the participants gained the ability to communicate successfully in intercultural texts by keeping a balance between self and other cultures.

\section{Discussion}

Compared with the pretreatment findings (Hazaea, 2018), the posttreatment findings showed a high level of self-esteem and appreciation of self and other cultures after introducing the levels of CDA. This improvement was manifested in the types of discourses evident in the participants' encounters with written discourse. The positive representation of self and other cultures was manifested in a number of discourses: self guest discourse in relation to other host discourse; Arab and Saudi identity in relation to American identity; discourse of time adaptation to self and other; discourse of mutual appreciation; discourse of mutual understanding; and discourse of mutual politeness.

The findings also indicated that the participants positively represented intercultural attitude after using
CDA tools. Intercultural attitude includes curiosity and discovering, respect, openness, and tolerating ambiguity (Deardorff, 2006). CDA proved to have a positive effect on mutual intercultural understanding. This was manifested in the discourses of mutual appreciation, mutual understanding, and mutual politeness. These findings are in agreement with Abbasian and Malaee (2015), who found that CDA techniques improved Iranian EFL learners' ability to read between the lines.

The positive attitude the present study identified also coincides with findings regarding positive attitude toward intercultural communication in the Chinese context. Liu and Fang (2017) found that most EFL Chinese students demonstrated a belief in the importance of intercultural awareness. Fang (2018) found that EFL Chinese students have positive attitudes toward intercultural citizenship and the English language. Similarly, Ko (2013) found that students develop critical consciousness of ideas that have been taken for granted after employing CDA in a critical-based literacy reading class.

Regarding appropriate intercultural knowledge, the participants represented this as well. Intercultural knowledge involves a combination of deep cultural knowledge and sociolinguistic awareness (Deardorff, 2006). When demonstrating their intercultural knowledge, participants manifested positive self cultural representation in self guest discourse, Arab regional discourse, Saudi national discourse, and time adaptation discourse. This finding coincides with previous researchers' findings (García \& Carmen, 2017; Ramos 2001). García and Carmen (2017) found that autobiographical writing production on intercultural encounters enhanced students' self-awareness. Similarly, Ramos (2001) found that Spanish students gained knowledge of self-awareness after implementing CDA.

Positive other culture representation was manifested in other host discourse, American national discourse, and time adaptation discourse. Mutual understanding was also achieved in terms of shared human values such as generosity and mutual relationships in 
communicative business events. In agreement with these discourses, Alfahadi (2012) found that Saudi EFL teachers are open to other cultures. In the same vein, Elyas' (2014) found that Saudi students firmly aligned themselves with master narratives relating to globalisation, the information age, and individuality.

In contrast, a space still remains as far as cultural identity is concerned. This was manifested in Saudi national discourse and Arab regional discourse in relation to American national discourse. These findings coincided with previous research. Huh and Suh (2017) found that critical citizenship literacy skills were directly juxtaposed with students' own and others' social contexts. Similarly, Ran (2008) found that the integration of one's native culture and the target culture can empower learners to experience language and culture learning at a deep level. Chen, Simmons, and Kang (2015) analyzed undergraduate American students' essays using CDA. However, they found that students believed in the ideology that identity was self-chosen; something that "embraces successes of multiracial/multicultural Americans as new markers of racial equality” (p. 180).

As previously stated, the participants' intercultural skills were demonstrated by their ability to use the CDA tools they were provided to analyze, interpret, and relate (Deardorff, 2006) in an intercultural clause. One finding was that Arab regional discourse replaced the assignment's Middle Eastern regional discourse. Another was that the sociocultural level of analysis was effective in terms of representing self and other ideologies. This was manifested in the repetition of the word culture in some discourses. Intercultural skills are shaped by linguistic factors. As previous research has shown, students with higher level in English skills tend to develop a more sophisticated critical stance toward the texts they engage with (Moncada Linares, 2016). Similarly, Marsh (2011) found that Japanese students with higher level in English skills increased intercultural skills. Escudero (2013) also found that drawing students' attention to the cultural situatedness of language use can increase their awareness of the multiple ideological positions existing in a cultural context. In the same vein, Hazaea and Alzubi (2017) found that employing CDA in an EFL reading classroom increased the participants' level of sociocultural understanding of the text. Finally, Dar, Shams, and Rahimi (2010) found that CDA increased students' level of critical language awareness by revealing the hidden layers of meaning implied in the texts.

Unlike the intercultural skills that students were found to have in the present study, Liu and Fang (2017) found superficial understanding of Chinese culture in an EFL Chinese context. Fang (2018) also found that EFL Chinese students gain their understanding and experience about intercultural communication more outside the classroom. The findings of this study support introducing CDA tools to enhance intercultural skills among EFL students. Furthermore, these findings indicate that CDA played an important role in greatly increasing the CIA levels of participants. CDA tools were effective in areas such as naming the social actors, modality, circumstances, and choice of verbal processes. The use of "social actors" (Van Leeuwen, 1996) was the main CDA tool helpful for CIA. These findings coincided with Rahimi (2013), who recommended CDA techniques to help students have a deeper understanding of reading texts. In addition, Molek-Kozakowska (2010) called for introducing CDA into education to enhance critical media literacy. Because the present study used newspaper texts, it also strengthens that call for incorporating CDA into EFL instruction and critical media literacy.

\section{Conclusion}

This paper shows the importance, use, and implications of CDA tools in EFL teaching and learning. It reports an investigation into CIA among EFL students in the context of a critical reading enrichment class in their preparatory year at a Saudi university. A group of students participated in a qualitative action research design. The participants were trained to use CDA tools for CIA, they were asked to critically read an intercultural text as an assignment and then 
creatively write about the discourse found throughout the text. The students' reflective writings were then compiled and analyzed using CDA tools.

Compared with the pretreatment findings (Hazaea, 2018), the analysis shows that the participants represented a high level of CIA at the posttreatment stage. They were able to associate the discourse of food diversity with intercultural competitive discourses. Intercultural attitude was represented in discourses of mutual appreciation, understanding, and politeness. Intercultural knowledge was portrayed in the discourse of self guest representation in relation to other host representation, the discourse of self as guest, the discourse of other as host, Saudi national discourse, American national discourse, Arab regional discourse, and time adaptation discourse. Intercultural skills were manifested in the participants' ability to use the CDA tools to decode the intercultural assignment, interpret embedded intercultural messages, and represent intercultural awareness in intercultural texts.

CDA proved to be effective for increasing CIA and contributed to EFL teaching and learning for intercultural communication. For teaching, CDA tools were introduced as a teaching method to enhance CIA. The same technique is recommended for EFL teachers to improve CIA among their students. For the learners in this study, the CDA tools got them to re-examine descriptive grammar to see it as functional grammar and use that knowledge to reveal hidden ideologies in the texts. Instead of being passive readers, the treatment encouraged critical thinking, learning autonomy, and research skills among the participants. It helped them to deconstruct and reconstruct intercultural texts. Using CDA tools also made the participants examine power relations in intercultural communication, which was manifested in the discussion between the self cultural group and the other cultural group: the self cultural group struggled to find its voice and space in intercultural texts.

The intercultural topic was a dinner invitation, which represents the surface aspect of culture. Further research could operationalize the objectivist as well as the ideologist positions on discourse to foster glocal citizenship in intercultural communication. The objectivist position would deal with global citizenship, such as poverty and climate change. This position on discourse is in agreement with the argument that English as an international language is no longer bound by American or British cultures; rather, it is used and taught as a means of communication devoid of cultural bonds to a particular culture. As such, both the objectivist and the ideologist positions can be used to investigate power relations over constructing glocal citizenship.

The type of text determines the effect of CDA tools on meaning making. Well-designed intercultural texts would be of great importance for building mutual understanding and intercultural communication. The intercultural texts used in this paper were traditional in their nature, either authentic textbook or newspaper texts. The intercultural assignment could have been better formulated in terms of gender construction.

These findings are limited to the 'world' of the texts in the study. Another limitation is that the time span was not long enough for the treatment because of the nature of the ungraded enrichment classes, which were treated as extracurricular activities. In other words, it would be much more effective to apply CDA for CIA in semester-long courses. Work on CDA is challenging in its nature. As a researcher in CDA, the teacher-researcher has keen interests in CDA, however, EFL teachers may need to be trained and equipped with CDA tools in order for them to guide the development of CIA among their students.

Further research could be conducted in the context of critical reading and creative writing courses. To assess CIA, researchers can also use other research tools such as recorded classroom conversation, peer observation and semi-structured interviews with students. Further research can also be implemented on multimodal intercultural texts such as films and social media networks to promote CIA and critical media literacy. 


\section{References}

Abbasian, G. R. \& Malaee, N. (2015). The Effect of Critical Discourse Analysis Instruction on Iranian EFL Learners' Reading Comprehension and Orientation. The Journal of Applied Linguistics, 8(17), 1-20.

Ahmad, J. (2015). Traditional \& socio-cultural barriers to EFL learning: A case study. English Language Teaching, 8(12), 191. https://doi.org/10.5539/elt.v8n12p191

Al-Ghamdi, A. \& Al-Saddat, I. (2002). The development of the educational system in Saudi Arabia. Riyadh: Tarbiat Al Ghad.

Aldosari, H. (2013). Integrating culture learning into foreign language education. Umm Al-Qurma University Journal of Languages and Literature, 11, 10-42.

Alfahadi, A. (2012). Saudi teachers' views on appropriate cultural models for efl textbooks: insights into TESOL teachers' management of global cultural flows and local realities in their teaching worlds. (Doctoral dissertation), University of Exeter, Exeter, uK. Retrieved from http://hdl.handle. net/10036/3875

Alkatheery, E. R., Al Saleh, P. \& Isama, M. (2010). Content analysis of culture in ELT reading textbooks: Appropriacy and inclusivity. (Master's thesis), King Saud University Riyadh.

Alonso, E. (2015). The impact of culture, religion and traditional knowledge on food and nutrition security in developing countries: Foodsecure Working paper no. 30. Centre for Institutions and Economic Performance, Department of Economics, KU Leuven, Leuven, Belgium.

Baker, W. (2012). From cultural awareness to intercultural awareness: Culture in ELT. ELT Journal, 66(1), 62-70. http://dx.doi.org/10.1093/elt/ccr017

Benahnia, A. (2014). The impact of cultural \& intercultural competence awareness programs on ESL scholarship candidates abroad. Paper presented at the Proceedings of International Academic Conferences.

Byram, M. (1997). 'Cultural awareness' as vocabulary learning. Language Learning Journal, 16(1), 51-57. https://doi. org/10.1080/09571739785200291

Chen, G. \& Starosta, W. (1998). A review of the concept of intercultural awareness. Human Communication, 2(1), 27-54.

Chen, Y., Simmons, N. \& Kang, D. (2015). “My Family Isn't Racist-However...": Multiracial/Multicultural Obama-ism as an Ideological Barrier to Teaching Intercultural Communication. Journal of International and Intercultural Communication, 8(2), 167-186. https://doi.org/10.1080/17513057.2015.1025331
Dar, Z. K., Shams, M. R. \& Rahimi, A. (2010). Teaching reading with a critical attitude: Using critical discourse analysis (CDA) to raise EFL university students' critical language awareness (CLA). International Journal of Criminology and Sociological Theory, 3(2).

Deardorff, D. K. (2006). Identification and assessment of intercultural competence as a student outcome of internationalization. Journal of Studies in International Education, 10(3), 241-266. http://dx.doi. org/10.1177/1028315306287002

Dudley-Evans, T. (2002). Genre analysis: An approach to text analysis for ESP. In M. Coulthard (Ed.), Advances in written text analysis. London: Routledge.

Elyas, T. (2008). The attitude and the impact of the American English as a global language within the Saudi education system. Novitas-Royal, 2(1), 28-48.

Elyas, T.(2011).Divergingidentities: a'contextualised'exploration of the interplay of competing discourses in two Saudi university classrooms. (Doctoral dissertation), The University of Adelaide, Adelaide, Australia. Retrieved from https://digital.library.adelaide.edu.au/dspace/ bitstream/2440/69220/8/02whole.pdf

Elyas, T. (2014). Exploring Saudi Arabia’s EFL Student Identity: A Narrative Critical Approach. International Journal of Applied Linguistics and English Literature, 3(5), 28-38. https://doi.org/10.7575/aiac.ijalel.v.3n.5p.28

Escudero, M. D. (2013). Teaching intercultural awareness in the English as a foreign language classroom: a case study using critical reading. Intercultural Education, 24(3), 251-263. http://dx.doi.org/10.1080/14675 986.2013.793037

Fageeh, A. (2011). At crossroads of EFL learning and culture: How to enhance cross-cultural awareness in EFL college students. Cross-Cultural Communication, 7(1), 62.

Fairclough, N. (1995). Media discourse. London: Edward Arnold.

Fairclough, N. (2003). Analysing discourse: Textual analysis for social research. London: Routledge. https://doi. org/10.4324/9780203697078

Fairclough, N. (2006). Language and globalization. London: Routledge. https://doi.org/10.4324/9780203593769

Fang, F., \& Baker, W. (2018). 'A more inclusive mind towards the world': English language teaching and study abroad in China from intercultural citizenship and English as a lingua franca perspectives. Language Teaching Research, 22(5), 608-624. https:// doi.org/10.1177/1362168817718574 
García, M. \& Carmen, M. (2017). Intercultural reflection through the autobiography of intercultural encounters: Students' accounts of their images of alterity. Language and Intercultural Communication, 17(2), 90-117. https://doi.org/10.1080/14708477.2016.1159693

Halliday, M. A. K. (1985). An introduction to functional grammar. London: Edward Arnold.

Hazaea, A., Noraini I. \& Nor Fariza M. (2014). Discursive legitimation of human values: Local-global power relations in global media discourse. GEMA Online Journal of Language Studies, 14(1), 171-187. http:// dx.doi.org/10.17576/GEMA-2014-1401-11

Hazaea, A., \& Alzubi, A. (2017). Effects of CDA instruction on EFL analytical reading practices. Novitas-ROYAL (Research on Youth and Language), 11(2), 88-101.

Hazaea, A. (2018). Investigation of intercultural competence: CDA of EFL students' baseline portfolios. BELT-Brazilian English Language Teaching Journal, 9(2), 458-475 http://dx.doi.org/10.15448/2178-3640.2018.2.31948

Ho, S. T. (2009). Addressing culture in EFL classrooms: The challenge of shifting from a traditional to an intercultural stance. Electronic Journal of Foreign Language Teaching, 6(1), 63-76.

Huckin, T. N. (1997). Critical discourse analysis. Document Resume, 87, 87-93.

Huh, S. \& Suh, Y. (2017). Preparing elementary readers to be critical intercultural citizens through literacy education. Language Teaching Research, http://dx.doi. org/10.1177/1362168817718575

Janks, H. (1997). Critical discourse analysis as a research tool. Discourse: studies in the cultural politics of education, 18(3), 329-342.

Kathpalia,S.S.\&Heah,C.(2008).Reflectivewriting:Insights into what lies beneath. RELC Journal, 39(3), 300317. https://doi.org/10.1177/0033688208096843

Kirn, E, \& Hartmann, P. (2012). Reading Interactions 1, Middle East diamond edition. New York:McGraw-Hill.

Ko, M. (2013). A critical discourse analysis of EFL learners' post-reading reflections in a critical literacy-based class. English Linguistics Research, 2(2), 1. https:// doi.org/10.5430/elr.v2n2p1

Korzilius, H. P. L. M., van Hooft, A. P. J. V., \& Planken, B. C. (2007). A longitudinal study on intercultural awareness and foreign language acquisition in the Netherlands. Journal of Intercultural Communication, 3(15). http://www.immi.se/intercultural/

Liu, J. \& Fang, F. (2017). Perceptions, awareness and perceived effects of home culture on intercultural communication: Perspectives of university students in China. System, 67, 25-37. https://doi. org/10.1016/j.system.2017.04.003

Mahboob, A. \& Elyas, T. (2014). English in the kingdom of Saudi Arabia. World Englishes, 33(1), 128-142. http://dx.doi.org/10.1111/weng.12073

Marsh, D. (2011). Using critical discourse analysis to raise critical language awareness in Japanese medical students: An exploratory action research project. (Master's thesis), University of Birmingham, Birmingham.

Molek-Kozakowska, K. (2010). Critical discourse analysis in media education: Some implications for critical media literacy. In A. Duszak, J. House, \& Ł. Kumięga (Eds.), Globalization, discourse, media: In critical perspective (pp. 113-130). Warsaw: Warsaw University Press.

Moncada L. S. (2016). Othering: Towards a critical cultural awareness in the language classroom. How, 23(1), 129146. http://dx.doi.org/10.19183/how.23.1.157

Nugent, K. \& Catalano, T. (2015). Critical cultural awareness in theforeignlanguageclassroom.NECTFLReview,75(1)1530.https://doi.org/10.1007/978-3-319-02325-0_16-1

Oranje, J. \& Smith, L. F. (2018). Language teacher cognitions and intercultural language teaching: The New Zealand perspective. Language Teaching Research, 22(3), 310329. http://dx.doi.org/10.1177/1362168817691319

Oughton, H. (2007). Constructing the 'ideal learner': A critical discourse analysis of the adult numeracy core curriculum. Research in Post-Compulsory Education, 12(2), 259275. https://doi.org/10.1080/13596740701387536

Porto, M., Houghton, S. A. \& Byram, M. (2018). Intercultural citizenship in the (foreign) language classroom. Language Teaching Research, 22(5), 484-498. http://dx.doi.org/10.1177/1362168817718580

Rahimi, S. (2013). Promoting the reading comprehension of high-school students through critical discourse analysis. Modern Journal of Language Teaching Methods, 3(4), 56.

Ramos, F. P. (2001). 'Why do they hit the headlines?': Critical media literacy in the foreign language class. Journal of Intercultural Studies, 22(1), 33-49. http:// dx.doi.org/10.1080/07256860120037409

Ran, Y. (2008). Integrating Chinese culture with Western culture in EFLT classroom. Paper presented at the Global Practices of Language Teaching: Proceedings of the 2008 International Online Language Conference (IOLC 2008). http://dx.doi.org/10.22158/selt.v4n3p376

Romova, Z. \& Andrew, M. (2011). Teaching and assessing academic writing via the portfolio: Benefits 
for learners of English as an additional language. Assessing Writing, 16(2), 111-122. http://dx.doi. org/10.1016/j.asw.2011.02.005

Svarstad, L. K. (2015). Cultural studies and critical discourse analysis in Class 8. Sprogforum, 60(1), 28-36.

Van Leeuwen, T. (1996). The representation of social actors. Texts and practices: Readings in critical discourse analysis, 1, 32-70.

Wallace, C. (1992). Critical literacy awareness in the EFL classroom. In N. Fairclough (Ed.), Critical language awareness (pp. 59-92). London: Longman.

Wallace, C. (1999). Critical language awareness: Key principles for a course in critical reading. Language awareness, 8(2), 98-110. https:// doi.org/10.1080/09658419908667121
Weninger, C. \& Kiss, T. (2013). Culture in English as a foreign language (EFL) textbooks: A semiotic approach. TESOL Quarterly, 47(4), 694-716. http:// dx.doi.org/10.1002/tesq.87

Wodak, R. (2002). What CDA is about - a summary of its history, important concepts and its developments. In R. Wodak \& M. Meyer (Eds.), Methods of critical discourse analysis (pp. 121-138). London: Sage.

Zhang, R. \& Steele, D. (2012). Improving intercultural awareness: a challenging task for Japan. Procedia-Social and Behavioral Sciences, 47(1), 52-63. http://dx.doi. org/10.1016/j.sbspro.2012.06.613

Zinkgraf, M. (2003). Assessing the development of critical language awareness in a foreign language environment. (ERIC Document Reproduction Service No. ED479811). https://eric.ed.gov/?id=ED479811

\section{Appendix: CDA Tools for Critical Intercultural Awareness}

\section{Text Analysis: (analyze the text through systemic functional grammar)}

Terms of Descriptive Grammar vis-à-vis terms of (Systemic Functional Grammar)

Unit of Analysis: Sentence (Clause)

Subject/object modal verbs Action Verbs Adverbial(time and place)

$\begin{array}{llll}\text { (Participants) (Circumstances) } & \text { (Modality) }\end{array}$

Subject Linking Verbs

(Carrier, Attribute) (Relational)

\section{Discourse Analysis:}

Writer(s) and readers: (ask questions about the writer(s) and target readers of the text)

Ask the following questions about discourse practice of the text.

Who are the writers of the text? Where are they from? 
Did they take the Saudi culture in mind when they wrote the text?

Did they take other cultures in mind when they wrote the text?

In your opinion, why did the writer choose the phrase ...?

Can this text be given to international students to learn about Saudi culture?

Is the text or parts of it were written by someone else in other texts such as newspapers? Search the internet to find out intertexuality of the text? If the answer is 'Yes', then the critical reader has to analyze the text in relation with the original (source) text.

\section{Critical Discourse Analysis:}

Society: (ask questions about your culture and other cultures in the text).

Ask the following questions about the intercultural practices of the text.

Do you agree with the writers about the image of Saudi culture in the text? If not, why?

Do you agree with the writers about the image of other cultures in the text? If not, why?

What is the 'point' of the text? What are the authors trying to tell us?

Any other questions about self culture and other cultures.

After the three overlapping layers of analysis, a student becomes critical analyst instead of mere passive reader. Accordingly, he understands the text and appreciates self and other cultures in the text. Finally, he can answer the questions about the text and/or he can write similar texts.

How to reference this article: Hazaea, Abduljalil (2020). Fostering Critical Intercultural Awareness among EFL Students through Critical Discourse Analysis. Íkala, Revista de Lenguaje y Cultura, 25(1), 17-33. doi: 10.17533/udea.ikala.v25n01a06 